\title{
A new species of Allocetraria (Parmeliaceae, Ascomycota) in China
}

\author{
Rui-Fang WANG, Xin-Li WEI and Jiang-Chun WEI
}

\begin{abstract}
Allocetraria yunnanensis R. F. Wang, X. L. Wei \& J. C. Wei is described as a new species from the Yunnan Province of China, and is characterized by having a shiny upper surface, strongly wrinkled lower surface, and marginal pseudocyphellae present on the lower side in the form of a white continuous line or spot. The phylogenetic analysis based on nrDNA ITS sequences suggests that the new species is related to $A$. sinensis X. Q. Gao.
\end{abstract}

Key words: Allocetraria yunnanensis, lichen, taxonomy

Accepted for publication 26 fune 2014

\section{Introduction}

The lichenized genus Allocetraria Kurok. \& M. J. Lai was described in 1991, with a new species $A$. isidiigera Kurok. \& M. J. Lai, and two new combinations: $A$. ambigua (C. Bab.) Kurok. \& M. J. Lai and A. stracheyi (C. Bab.) Kurok. \& M. J. Lai (Kurokawa \& Lai 1991). The main distribution area of Allocetraria species was reported to be in the Himalayas, including China, India, and Nepal.

Allocetraria is characterized by dichotomously or subdichotomously branched lobes and a foliose to suberect or erect thallus with sparse rhizines, angular to sublinear pseudocyphellae, palisade plectenchymatous upper cortex, as well as producing usnic acid but never atranorin (Kurokawa \& Lai 1991). It is a well-supported monophyletic group within the cetrarioid clade in Parmeliaceae (Saag et al. 2002; Thell et al. 2009; Nelsen et al. 2011). Ten species of Allocetraria have been accepted in the genus worldwide; China is the main distribution area of the

R.-F. Wang, X.-L. Wei and J.-C. Wei (co-corresponding author): State Key Laboratory of Mycology, Institute of Microbiology, Chinese Academy of Sciences, Beijing 100101, China. Email: weixl@im.ac.cn,weijc2004@126. com

R.-F. Wang: College of Life Sciences, Shandong Agricultural University, Tai'an 271000, China. genus, as all ten species have been reported there (Kurokawa \& Lai 1991; Thell et al. 1995; Randlane et al. 2001; Wang et al. 2014). During our taxonomic study of Allocetraria, a new species was found.

\section{Materials and Methods}

A dissecting microscope (ZEISS Stemi SV11) and compound microscope (ZEISS Axioskop 2 plus) were used to study the morphology and anatomy of the specimens. Colour test reagents $[10 \%$ aqueous $\mathrm{KOH}$, saturated aqueous $\mathrm{Ca}(\mathrm{OCl})_{2}$, and concentrated alcoholic $p$ phenylenediamine] and thin-layer chromatography (TLC, solvent system C) were used for the detection of lichen substances (Culberson \& Kristinsson 1970; Culberson 1972).

Nineteen fresh specimens were chosen for DNA extraction (Table 1), in which eight species of Allocetraria were included. The remaining three species of the genus, A. capitata R. F. Wang et al., $A$. denticulata (Hue) A. Thell \& Randlane and $A$. isidiigera, are absent because of a lack of fresh specimens and corresponding sequences in NCBI. The extraction procedure followed the modified CTAB method (Rogers \& Bendich 1988). PCR amplifications were performed using a Biometra T-Gradient thermal cycler. The primer pairs ITS1 (White et al. 1990) and LR1 (Vilgalys \& Hester 1990) were used to amplify the nrDNA ITS regions. Twenty-seven sequences were aligned with the program MEGA5 (Tamura et al. 2011); 19 specimens were sequenced by the authors, and 8 sequences were downloaded from GenBank, including outgroups Tuckermanopsis ciliaris (Ach.) Gyeln., Usnocetraria oakesiana (Tuck.) M. J. Lai \& J. C. Wei, and Vulpicida juniperinus (L.) J. E. Mattsson \& M. J. Lai. The phylogenetic analysis was executed with MEGA5. Model 


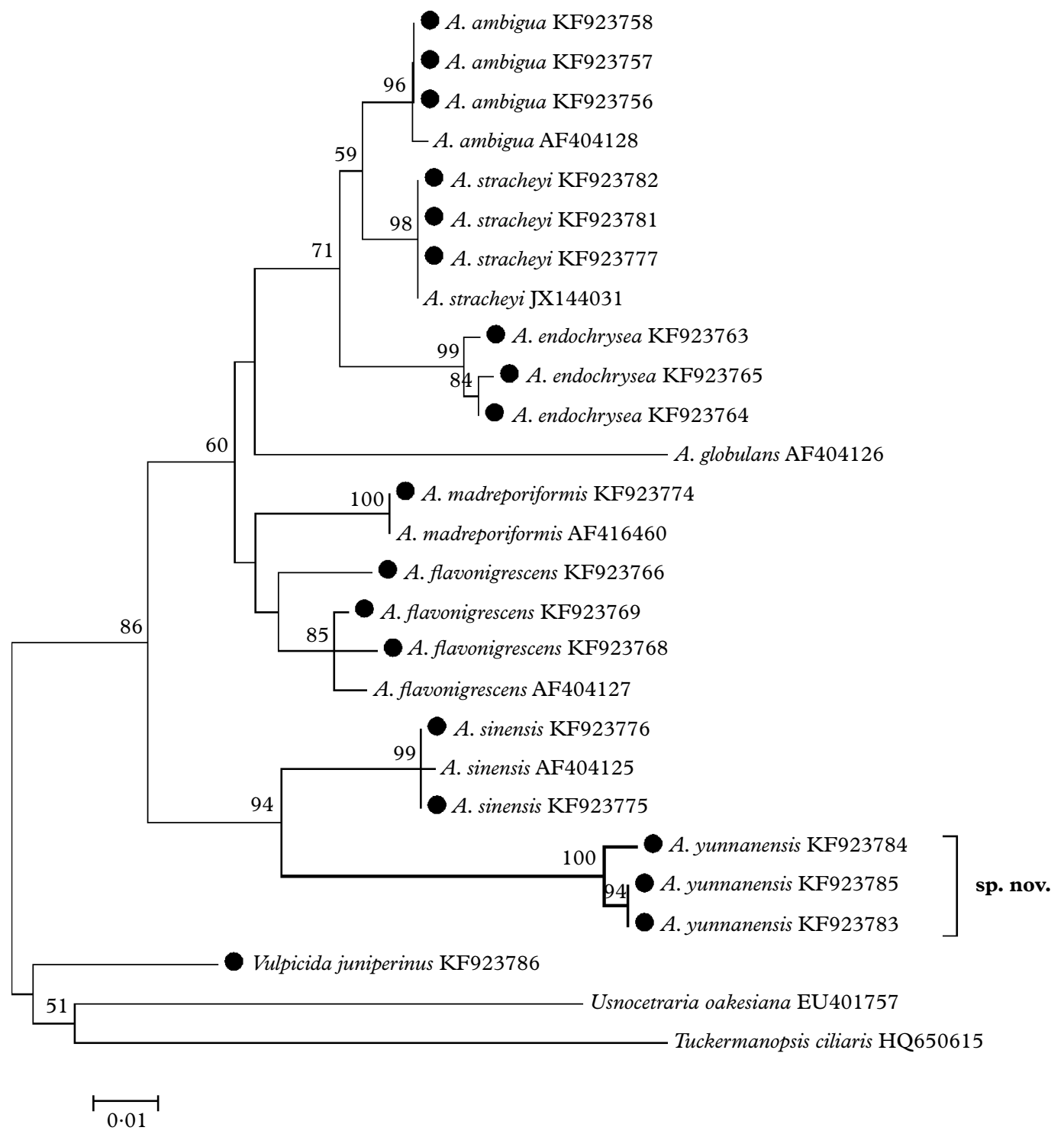

FIG. 1. The ML tree based on nrDNA ITS region sequences, the specimens marked with ' $\bullet$ ' were examined by the authors. Nucleotide: TN93+G model, bootstrap $=1000$. Genetic distance scale $=0 \cdot 01$. The number at each node represents bootstrap support value (numbers lower than 50 are not shown).

TN93+G was set according to the lowest BIC scores (Bayesian Information Criterion). The Maximum Likelihood (ML) method was used in constructing the phylogenetic tree and the reliability of the inferred tree was tested by 1000 bootstrap replications.

\section{Results and Discussion}

The ML tree (Fig. 1) based on the ITS sequences demonstrates that the eight species of Allocetraria clustered into a moderately well-supported ( $86 \%$ bootstrap value) monophyletic clade. Allocetraria yunnanensis R. F. Wang et al. is well clustered (94\% bootstrap value) together with the similar species $A$. sinensis X. Q. Gao as a separate group, despite their obvious differences. Therefore $A$. yunnanensis is a new species, well supported by DNA data. 

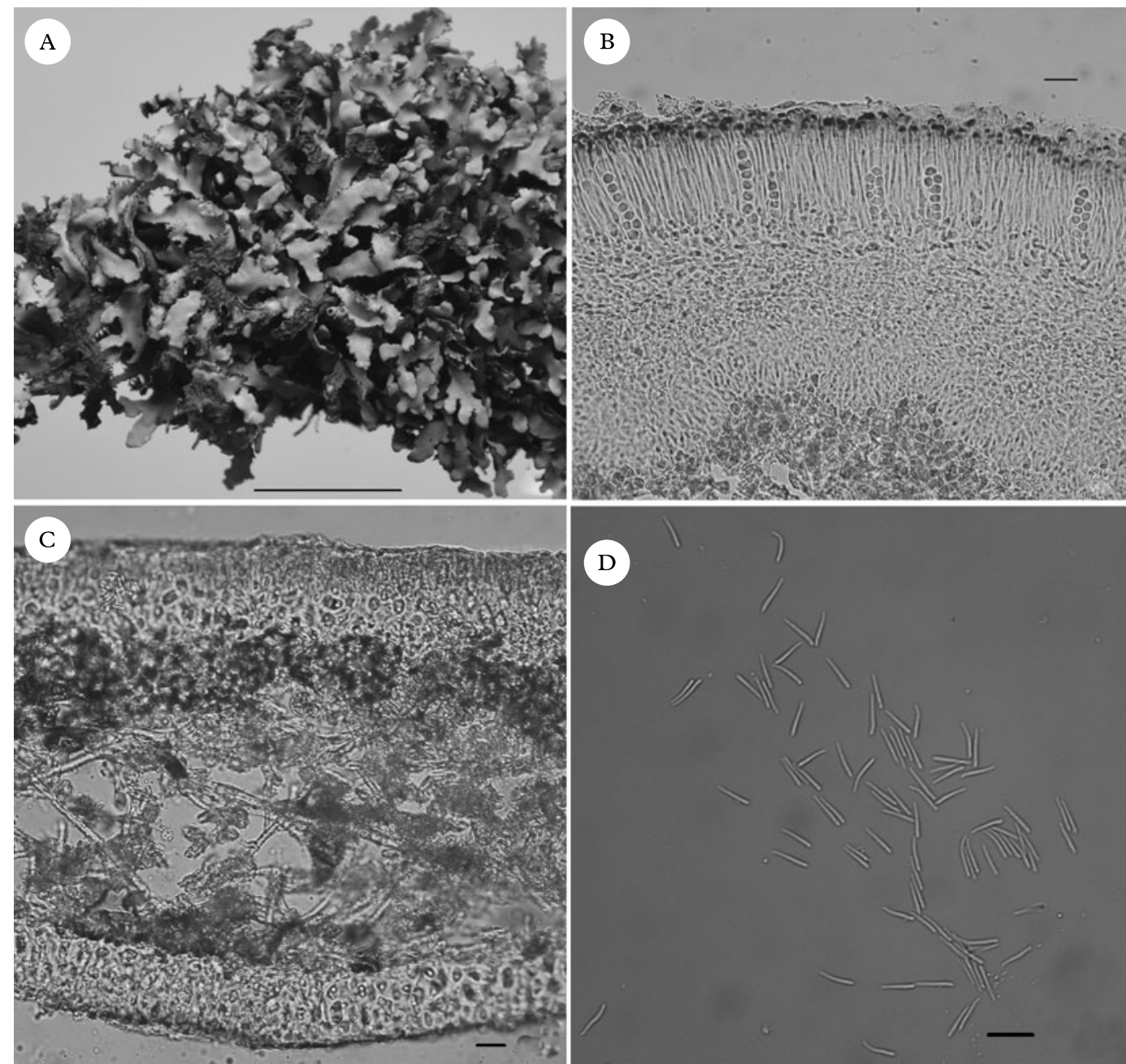

Fig. 2. Allocetraria yunnanensis R. F. Wang, X. L. Wei \& J. C. Wei, sp. nov. (holotype). A, habit; B, anatomy of apothecium in vertical section; $C$, longitudinal section of the thallus; $D$, pycnoconidia. Scales: $A=1 \mathrm{~cm}$; $\mathrm{B}-\mathrm{D}=20 \mu \mathrm{m}$.

\section{The New Species}

\section{Allocetraria yunnanensis R. F. Wang, X. L. Wei \& J. C. Wei sp. nov.}

\section{MycoBank No.: MB809069}

Similar to $A$. sinensis in habitus, but differs from the latter and all other members in the genus by having a shiny upper surface and a lower surface which is strongly wrinkled and has marginal pseudocyphellae present on the lower side in the form of a white continuous line or spot.

Type: China, Yunnan Province, Deqin County, Meli Village, Meili Snow Mountain, on soil, $28^{\circ} 38 \cdot 191^{\prime} \mathrm{N}$, $98^{\circ} 36 \cdot 304^{\prime} \mathrm{E}$, alt. $4800 \mathrm{~m}, 10$ September 2012, R. F. Wang YK12012 (HMAS-L128218-holotype).

\section{(Fig. 2)}

Thallus foliose, suberect to prostrate, dorsiventral, caespitose, $1.0-1.5 \mathrm{~cm}$ high. Lobes narrow, 1-4 mm wide, 200-350 $\mu \mathrm{m}$ thick, sublinear-elongate, flat to slightly concave, irregularly branched lobules. Upper surface greenish yellow to yellow or green, smooth, slightly shiny. Lower surface white to brown or almost dark brown, strongly 
wrinkled, dull. Pseudocyphellae located on the ridges of the lower surface, forming a continuous line or spot. Rhizines marginal on the lower side, sparse, simple, dark, 1-2 mm long. Epicortex 10-15 $\mu \mathrm{m}$ thick, non-cellular; upper cortex $30-60 \mu \mathrm{m}$ thick, more or less palisade plectenchymatous; lower cortex 35$50 \mu \mathrm{m}$ thick, more or less palisade plectenchymatous. Medulla light yellow to yellow.

Apothecia rare, terminal or marginal, up to $6 \mathrm{~mm}$ diam., with brown disc; thalline margin rather thick and crenulate. Asci narrowly cylindrical $35-50 \times 10-15 \mu \mathrm{m}$; ascospores globose, 5-9 $\mu \mathrm{m}$ diam., or subglobose, 6$8 \times 5-7 \mu \mathrm{m}$.

Pycnidia marginal, frequent, black, on emergent projections; pycnoconidia filiform, one end slightly swollen, $10-18 \times 1 \cdot 0-2 \cdot 5 \mu \mathrm{m}$.

Chemistry. Lichesterinic, protolichesterinic, secalonic and usnic acids; cortex $\mathrm{K}-, \mathrm{KC}+$ yellow; medulla $\mathrm{K}-, \mathrm{C}-$, $\mathrm{KC}-$, PD-.

Etymology. The epithet 'yunnanensis' is derived from the locality of the new species 'Yunnan', a province of China. Known only from the type locality.

Ecology and substratum. On the ground, mixed with moss.

Specimens examined. China: Yunnan Province: Deqin County, Meli Village, Meili Snow Mountain, on soil, $28^{\circ} 38 \cdot 191^{\prime} \mathrm{N}, 98^{\circ} 36 \cdot 304^{\prime} \mathrm{E}$, alt. $4800 \mathrm{~m}, 2012, R$. F. Wang YK12004 (HMAS-L-128219), YK12018 (HMASL-128220).

This project was supported by the National Natural Science Foundation of China (31200018) and the Main Direction Program of Knowledge Innovation of the Chinese Academy of Sciences (KSCX2-EW-Z-9). We thank Ms. H. Deng for providing considerable assistance during the studies in HMAS-L.

\section{REFERENCES}

Culberson, C. F. (1972) Improved conditions and new data for the identification of lichen products by a standardized thin-layer chromatographic method. fournal of Chromatography 72: 113-125.
Culberson, C. F. \& Kristinsson, H. (1970) A standardized method for the identification of lichen products. Fournal of Chromatography 46: 85-93.

Kurokawa, S. \& Lai, M. J. (1991) Allocetraria, a new genus in the Parmeliaceae. Bulletin of the National Science Museum (Tokyo), B 17: 59-65.

Nelsen, M. P., Chavez, N., Sackett-Hermann, E., Thell, A., Randlane, T., Divakar, P. K., Rico, V. J. \& Lumbsch, H. T. (2011) The cetrarioid core group revisited (Lecanorales: Parmeliaceae). Lichenologist 43: $537-551$.

Randlane, T., Saag, A. \& Obermayer, W. (2001) Cetrarioid lichens containing usnic acid from the Tibetan area. Mycotaxon 80: 389-425.

Rogers, S. O. \& Bendich, A. J. (1988) Extraction of DNA from plant tissues. In Plant Molecular Biology Manual (S. B. Gelvin \& R. A. Schilperoort, eds) A6: 1-10. Boston: Kluwer Academic Publishers.

Saag, A., Randlane, T., Thell, A. \& Obermayer, W. (2002) Phylogenetic analysis of cetrarioid lichens with globose ascospores. Proceedings of the Estonian Academy of Sciences, Biology, Ecology 51: 103-123.

Tamura, K., Peterson, D., Peterson, N., Stecher, G., Nei, M. \& Kumar, S. (2011) MEGA5: molecular evolutionary genetics analysis using maximum likelihood, evolutionary distance, and maximum parsimony methods. Molecular Biology and Evolution 28: 2731-2739.

Thell, A., Randlane, T., Kärnefelt, I., Gao, X. Q. \& Saag, A. (1995) The lichen genus Allocetraria (Ascomycotina, Parmeliaceae). In Contributions to Lichenology in Honour of Gerhard Follmann (F. J. Daniels, M. Schulz \& J. Peine, eds.): 353-370. Cologne: Botanical Institute, University of Cologne.

Thell, A., Högnabba, F., Elix, J. A., Feuerer, T., Kärnefelt, I., Myllys, L., Randlane, T., Saag, A., Stenroos, S., Ahti, T., Seaward, M. R. D. (2009) Phylogeny of the cetrarioid core (Parmeliaceae) based on five genetic markers. Lichenologist 41: 489-511.

Vilgalys, R. \& Hester, M. (1990) Rapid genetic identification and mapping of enzymatically amplified ribosomal DNA from several Cryptococcus species. Fournal of Bacteriology 172: 4238-4246.

Wang, R. F., Wang, L. S. \& Wei, J. C. (2014). Allocetraria capitata sp. nov. (Parmeliaceae, Ascomycota) from China. Mycosystema 33: 1-4.

White, T. J., Bruns, T., Lee, S. \& Taylor, J. W. (1990) Amplification and direct sequencing of fungal ribosomal RNA genes for phylogenetics. In PCR Protocols: a Guide to Methods and Applications (M. A. Innis, D. H. Gelfand, J. J. Sninsky \& T. J. White, eds): 315-322. San Diego, California: Academic Press. 